\title{
Zn(II) and Co(II) 3D Coordination Polymers Based on 2-Iodoterephtalic Acid and 1,2-bis(4-pyridyl)ethane: Structures and Sorption Properties
}

\author{
Alexander S. Zaguzin ${ }^{1,2}$, Taisiya S. Sukhikh ${ }^{2} \mathbb{D}$, Ilyas F. Sakhapov ${ }^{1,3}$, Vladimir P. Fedin ${ }^{2}$, Maxim N. Sokolov ${ }^{2} \mathbb{D}$ \\ and Sergey A. Adonin 1,2,* \\ 1 South Ural State University, Lenina St. 76, 454080 Chelyabinsk, Russia; zaguzin@niic.nsc.ru (A.S.Z.); \\ sakhapovilyas@mail.ru (I.F.S.) \\ 2 Nikolaev Institute of Inorganic Chemistry, SB RAS, Lavrentieva St. 3, 630090 Novosibirsk, Russia; \\ sukhikh@niic.nsc.ru (T.S.S.); cluster@niic.nsc.ru (V.P.F.); caesar@niic.nsc.ru (M.N.S.) \\ 3 Arbuzov Institute of Organic and Physical Chemistry, RAS, Arbuzov St. 8, 420088 Kazan, Russia \\ * Correspondence: adonin@niic.nsc.ru
}

check for

updates

Citation: Zaguzin, A.S.; Sukhikh, T.S.; Sakhapov, I.F.; Fedin, V.P.; Sokolov, M.N.; Adonin, S.A. Zn(II) and Co(II) 3D Coordination Polymers Based on 2-Iodoterephtalic Acid and 1,2-bis(4-pyridyl)ethane: Structures and Sorption Properties. Molecules 2022, 27, 1305. https://doi.org/ 10.3390/molecules 27041305

Academic Editor: Takashiro Akitsu

Received: 14 January 2022

Accepted: 6 February 2022

Published: 15 February 2022

Publisher's Note: MDPI stays neutral with regard to jurisdictional claims in published maps and institutional affiliations.

Copyright: () 2022 by the authors Licensee MDPI, Basel, Switzerland. This article is an open access article distributed under the terms and conditions of the Creative Commons Attribution (CC BY) license (https:// creativecommons.org/licenses/by/ $4.0 /)$.

\begin{abstract}
Metal-organic frameworks [M $\left.\mathrm{M}_{2}(2-\mathrm{I}-\mathrm{bdc})_{2} \mathrm{bpe}\right](\mathrm{M}=\mathrm{Zn}(\mathrm{II})$ (1), Co(II) (2), 2-I-bdc = 2iodoterephtalic acid, and bpe =1,2-bis(4-pyridyl)ethane) were prepared and characterized by X-ray diffractometry. Both compounds retain their 3D structure after the removal of guest DMF molecules. Selectivity of sorption of different organic substrates from the gas phase was investigated for both complexes.
\end{abstract}

Keywords: zinc; metal-organic frameworks; coordination polymers; carboxylates; sorption

\section{Introduction}

Metal-organic frameworks, or MOFs, constitute a very important class of coordination compounds that remain a "hot topic" within the last decades [1-9]. Among the potential application areas making MOFs attractive objects, there are sensors, including detection of explosives, toxins, or even cancer biomarkers [8,10-16], catalysis [17-23], and separation of different substrates (hydrocarbons [24,25], etc.). The latter field is especially important since different MOFs can demonstrate remarkable sorption selectivity towards mixtures that are relevant to those occurring in real industrial processes-for example, cyclohexane/benzene [26-31], hexane/cyclohexane, [32] acetylene/alkanes [33-35], etc. MOFs can also be used for the removal of contaminants (both organic and inorganic) from water [36-38].

The sorption ability of MOFs is closely related to the features of supramolecular contacts between organic ligands and guest molecules. These non-covalent interactions can be different. Usually, the main role is played by hydrogen bonding, but reports also appear where other types of supramolecular interactions, in particular, halogen bonding (XB) [39], have a major contribution. These examples are yet rare [40-42], but, in our opinion, they demonstrate that this topic can evolve further.

Among the great variety of building blocks able to form $\mathrm{XB}$, there are halogenated hydrocarbons (alkanes [43-46] and, less commonly, alkynes [47,48]), perfluorinated iodoarenes [49-52], di- and polyhalogens [53-55], complexes with halogen-substituted pyridines [56-60], etc. For the design of MOFs, halogen-substituted aromatic polycarboxylic acids seem to be the suitable option: it can be assumed that halogens, especially iodine, can feature the presence of sigma-hole due to the impact of electron-withdrawing carboxylic groups. Of this family, 2-iodoterephtalic acid (2-I-bdc) is easily available [61]; very recently, we reported in [62] corresponding on [ $\left.\mathrm{Zn}_{2}(\mathrm{I}-\mathrm{bdc})_{2} \mathrm{dabco}\right] \mathrm{MOF}$ and compared its sorption selectivity towards different organic substrates with parent [ $\mathrm{Zn}_{2} \mathrm{bdc}_{2} \mathrm{dabco}_{\text {. }}$ 
Continuing this work, we changed the N,N-linker ligand for 1,2-bis(4-pyridyl)ethane (bpe) and hereby present two new coordination polymers-[M $\left.\mathrm{M}_{2}(2-\mathrm{I}-\mathrm{bdc})_{2} \mathrm{bpe}\right](\mathrm{M}=\mathrm{Zn}$ (II) (1) and $\mathrm{Co}(\mathrm{II})$ (2). Both compounds feature 3D structure; sorption selectivity was investigated and compared for 1 and 2.

\section{Results and Discussion}

The structures of $\mathbf{1}$ and $\mathbf{2}$ are based on similar building blocks. In both cases, there form dimeric paddlewheel-type $\left\{\mathrm{M}_{2}(\mathrm{OOCR})_{4}(\mathrm{bpe})_{2}\right\}$ units (Figure 1$)$, very common for carboxylate complexes. The M-O bond lengths in $\mathbf{1}$ and $\mathbf{2}$ are 2.029-2.051 and 2.013-2.036 $\AA$, respectively, the M-N bonds are 2.019-2.030 and $2.044 \AA$, respectively. The iodine atoms of 2-I-bdc ligands are disordered over three positions in both structures (the occupancies are 0.444:0.307:0.249 and 0.641:0.160:0.199, respectively). In structure 1, one of two arene rings in bpe ligand is disordered as well (two positions with 0.68:0.32 occupancy).

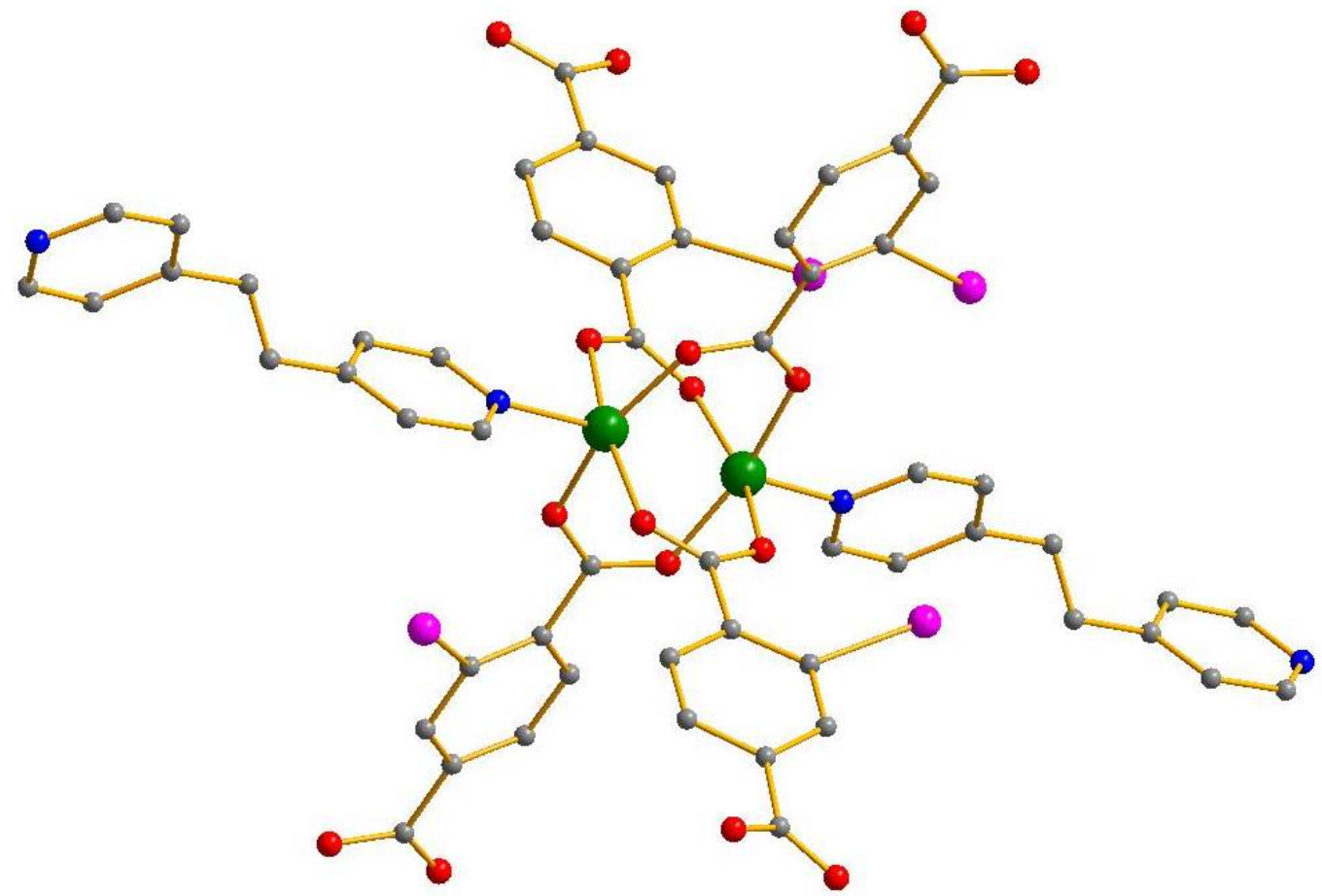

Figure 1. Coordination unit in structures 1 and 2. Metal green, $\mathrm{C}$ grey, $\mathrm{O}$ red, I purple, $\mathrm{N}$ deep blue. $\mathrm{H}$ atoms are omitted for clarity, only one of three possible positions of $\mathrm{I}$ is shown.

The $\left\{\mathrm{M}_{2}(\mathrm{I}-\mathrm{bdc})_{4}\right\}$ secondary building units are further connected via bpe ligands to a cuboid framework with rhombic-rod pores. Previously reported non-iodinated congener, [ $\left.\mathrm{Zn}_{2}(\mathrm{bdc})_{2}(\mathrm{bpe})\right]$ [63], reveals a tetragonal structure with bpe disordered over eight positions due to its proximity to a special position $(4 / \mathrm{mmm})$. Compound 1 comprises more ordered bpe (two crystallographically independent ligands) and two independent I-bdc ligands (Figure 2), thereby exhibiting a less symmetrical structure of ca. 4-fold increased cell volume as compared to $\left[\mathrm{Zn}_{2}(\mathrm{bdc})_{2}(\mathrm{bpe})\right]$. For 1 , the non-equivalence of the bpe and I-bdc ligands manifest in a different relative arrangement of the aromatic rings and (in the case of I-bdc) in a different disorder pattern of I atoms. 

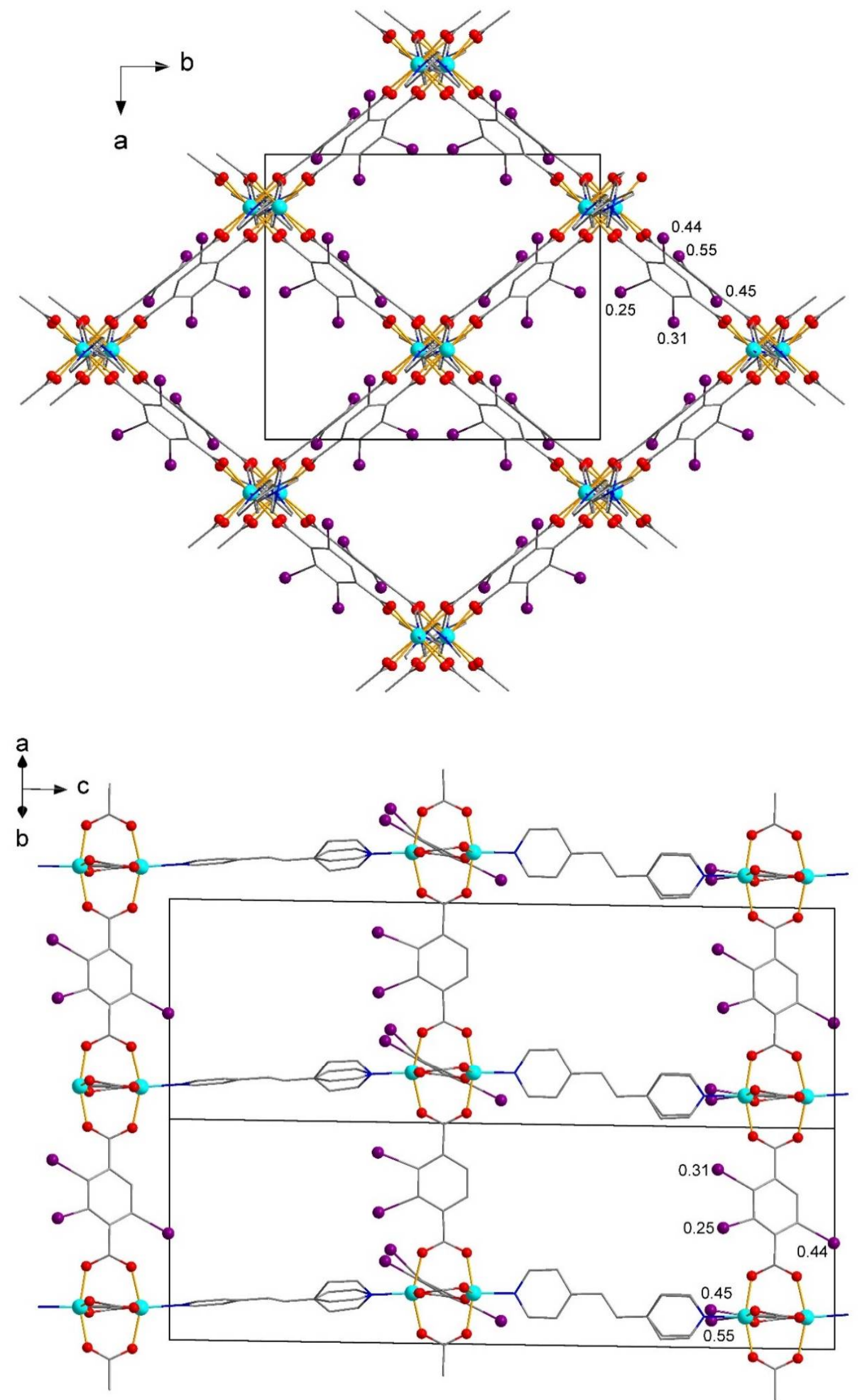

Figure 2. A fragment of the framework of 1. Hydrogen atoms are omitted, the occupancy of disordered I atoms is shown. 
The structure of $\mathbf{2}$ is more symmetrical (namely, it has fewer translational symmetry elements per the same fragment of the structure), comprising only one independent I-bdc and half of bpe ligand (Figure 3). In structures of $\mathbf{1}$ and $\mathbf{2}$, the frameworks show two-fold interpenetration (Figure 4), which reduces the volume of voids accessible for the inclusion of solvate molecules. The potential volume is estimated to be $22 \%$ and $25 \%$ from the total volume of structures 1 and 2, respectively, although the actual values are higher due to the unaccounted volume taken by the disordered atoms. The topology of MOFs $\mathbf{1}$ and $\mathbf{2}$ is shown in Figure 5.

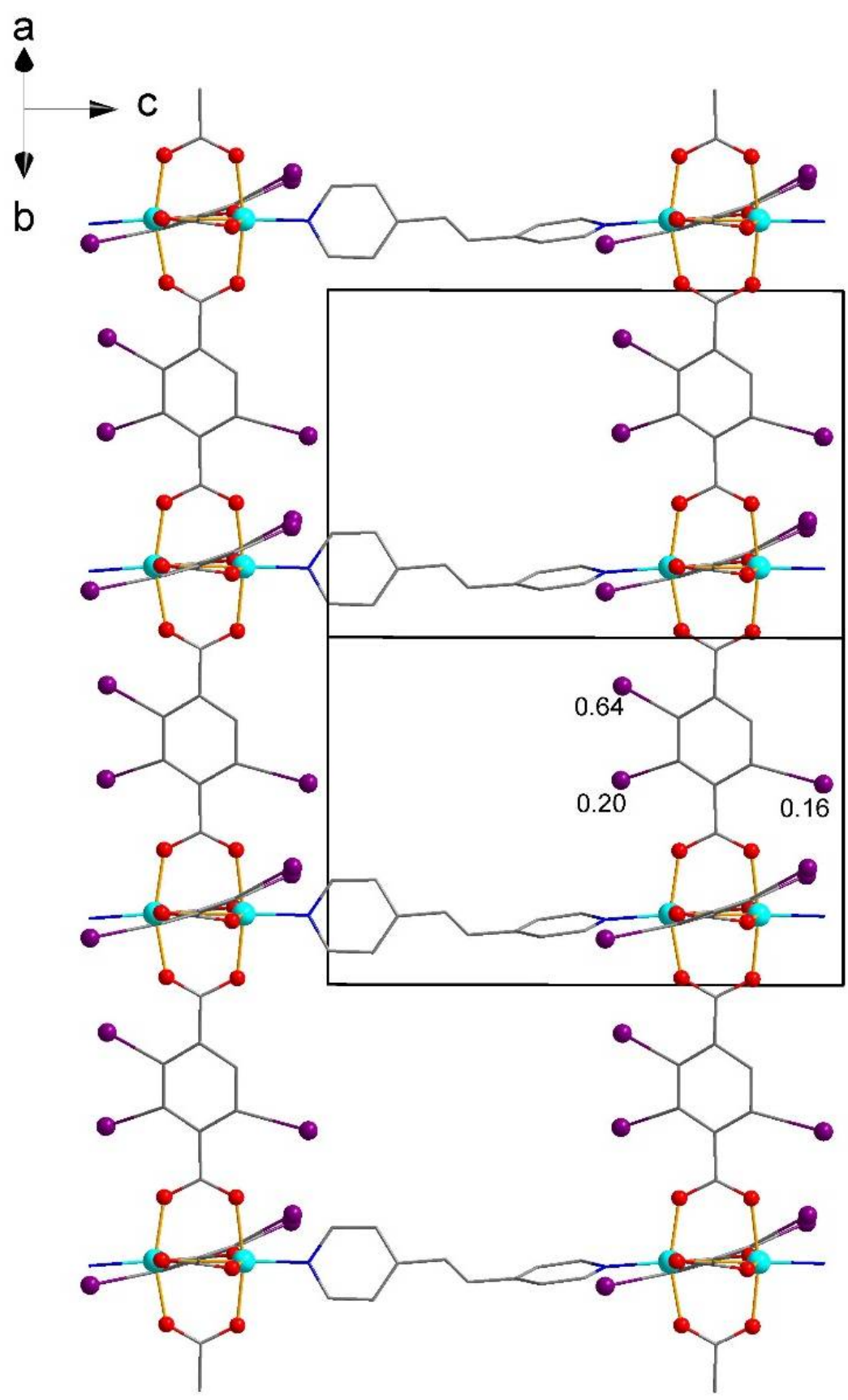

Figure 3. A fragment of the framework of 2. Hydrogen atoms are omitted, the occupancy of disordered I atoms is shown. 


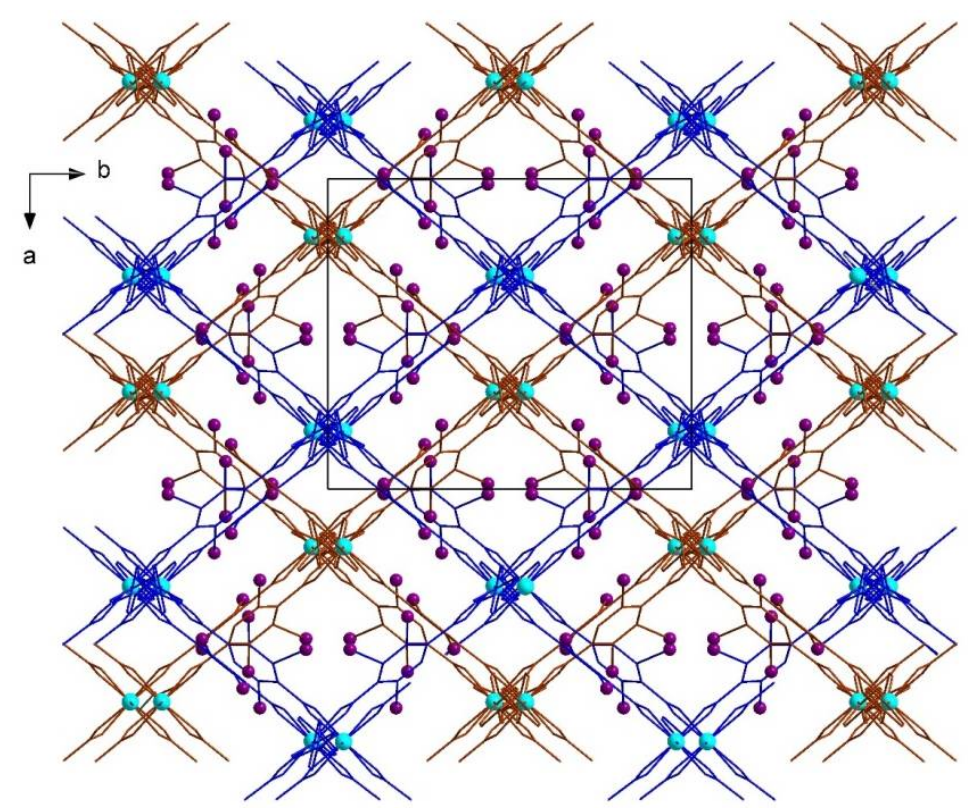

Figure 4. A fragment of the structures of the compounds on the example of 2 showing interpenetrated frameworks colored with blue and brown.

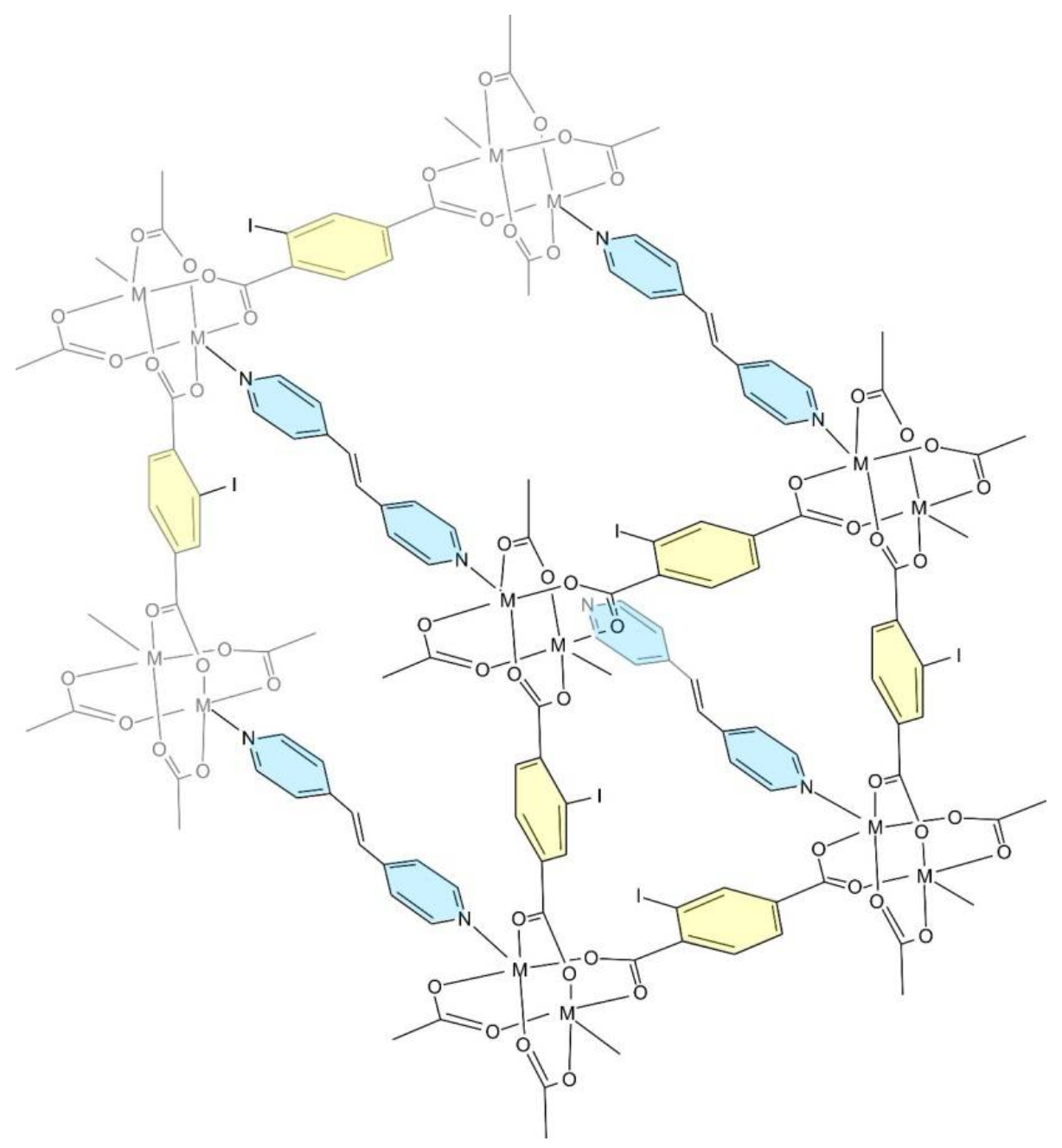

Figure 5. A fragment of the structures of the compounds in the example of $\mathbf{2}$ showing interpenetrated frameworks colored with blue and brown. 
The experimental PXRD pattern for 1 resembles that for the sub-structure akin to 2 (Figure S1); compound 1 retains its structure after the removal of guest DMF molecules (see Experimental for details). The notable difference between the experimental and simulated patterns of $\mathbf{1}$ may arise from a slight change of the structure upon partial loss of solvate molecules under sample preparation and/or due to difference in the temperature of the single-crystal $(150 \mathrm{~K})$ and powder $(298 \mathrm{~K})$ experiments. To clarify this, we carried out PXRD experiments at $150 \mathrm{~K}$ for an as-synthesized sample under a small amount of the mother liquor; the data was in better agreement with the simulated pattern of the sub-structure. A few superstructural reflections were observed; however, they did not correspond to super-structure 1 . The presence of sub- and super-structures for the family of MOFs seemed to be common. For instance, related MOFs formulated as $\left[\mathrm{Zn}_{2}(\mathrm{bdc})_{2}(\mathrm{dabco})\right]$ (dabco is 1,8-diazabicyclooctane) revealed a variety of cuboid structures of the same topology that differ from each other mainly by spatial geometry of $\{\mathrm{Zn}(\mathrm{bdc})\}$ layers [62]. Relatively poor quality of the PXRD pattern of $\mathbf{1}$ did not allow us to evaluate the superstructural motif. The PXRD for a sample of 1 dried naturally, measured at $150 \mathrm{~K}$ (Figure S3, SI), slightly differed from that with the mother liquor, implying minor structural transformations upon partial loss of the solvate. It became similar to the room-temperature patterns for as-synthesized and activated samples (Figure S1). The same trend was observed for the PXRD patterns of sample 2 (Figures S2 and S4). Upon activation of sample 2, the structure changes more noticeably, which was reflected in the appearance of strong superstructural reflections.

Sorption selectivity of $\mathbf{1}$ and $\mathbf{2}$ towards different organic substrates was examined using NMR (see Supplementary Information for NMR spectra). Results are given in Table 1.

Table 1. Selectivity of vapor adsorption by $\mathbf{1}, \mathbf{2},\left[\mathrm{Zn}_{2}(2-\mathrm{I}-\mathrm{bdc})_{2}\right.$ dabco] and $\left[\mathrm{Zn}_{2}(\mathrm{bdc})_{2}\right.$ dabco] [62] from equimolar mixtures of different organic substrates.

\begin{tabular}{|c|c|c|c|c|c|}
\hline No. & Substrates & 1 & 2 & {$\left[\mathrm{Zn}_{2}(2-\mathrm{I}-\mathrm{bdc})_{2} \mathrm{dabco}\right]$} & {$\left[\mathrm{Zn}_{2}(\mathrm{bdc})_{2} \mathrm{dabco}\right]$} \\
\hline 1 & 1,2-dichloroethane:benzene & $2.54: 1$ & $2.57: 1$ & $1.5: 1$ & $1.2: 1$ \\
\hline 2 & Chloroform:benzene & $3.3: 1$ & $1: 1$ & $1.3: 1$ & $2.0: 1$ \\
\hline 3 & Benzene:cyclohexane & $43.8: 1$ & $10: 1$ & $15: 1$ & $25: 1$ \\
\hline 4 & 1,2-dibromoethane:benzene & $8.3: 1$ & $3.1: 1$ & $\mathrm{n} / \mathrm{a}$ & $\mathrm{n} / \mathrm{a}$ \\
\hline 5 & 1-butanol:1-bromobutane & $1.3: 1$ & $1.17: 1$ & $0.38: 1$ & $0.5: 1$ \\
\hline
\end{tabular}

Both 1 and 2 more readily absorbed 1,2-dichloroethane from its mixture with benzene than MOFs of the dabco family. Although the difference was not large, these results are rather inspiring. The best selectivity was demonstrated by $\mathbf{1}$ for benzene/cyclohexane mixtures-it exceeded one of [ $\mathrm{Zn}_{2}(\mathrm{bdc})_{2}$ dabco]. Interestingly, the selectivity in 1-butanol/1bromobutane pair was reversed for bpe and dabco series; the reasons for this effect are unclear.

\section{Materials and Methods}

All reagents were obtained from commercial sources and used as purchased. Solvents were purified according to the standard procedures. 2-iodoterephtalic acid was prepared according to the method reported earlier [61] and identified by its ${ }^{1} \mathrm{H}$ and ${ }^{13} \mathrm{C} \mathrm{NMR}$ spectra.

Synthesis of 1

Seventy-four and a half micrograms $(0.25 \mathrm{mmol})$ of $\mathrm{Zn}\left(\mathrm{NO}_{3}\right)_{2} \cdot 6 \mathrm{H}_{2} \mathrm{O}, 73 \mathrm{mg}(0.25 \mathrm{mmol})$ of 2-I-bdc, $23 \mathrm{mg}(0.125 \mathrm{mmol})$ of bpe, and $8 \mathrm{~mL}$ of anhydrous DMF were placed into a glass ampoule which was sealed, kept in an ultrasonic bath for $10 \mathrm{~min}$ and kept at $120^{\circ} \mathrm{C}$ for $48 \mathrm{~h}$ with slow cooling to room temperature-forming colorless crystals of 1 with a $79 \%$ yield. 


\section{Synthesis of 2}

The procedure was the same as for $\mathbf{1}$, using $119 \mathrm{mg}(0.5 \mathrm{mmol})$ of $\mathrm{CoCl}_{2} \cdot 6 \mathrm{H}_{2} \mathrm{O}, 146 \mathrm{mg}$ ( $0.5 \mathrm{mmol})$ of 2-I-bdc, $46 \mathrm{mg}(0.25 \mathrm{mmol})$ of bpe, and $7.5 \mathrm{~mL}$ of anhydrous DMF-forming deep blue colorless crystals of 2 with a $73 \%$ yield.

\section{Sorption of organic substrates}

The method was identical to one described by us earlier [62]. Prior to sorption experiments, samples of 1 or 2 were kept in excess of acetone for $48 \mathrm{~h}$, followed by drying in vacuo $\left(4 \mathrm{~h}, 60^{\circ} \mathrm{C}\right)$ in order to eliminate guest DMF molecules. After that, the sample of MOF (50 mg) was placed into an open smaller vial, which was then placed into the closed bigger vial containing a mixture of organic substrates in 1:1 $\mathrm{M}$ ratio so that the liquid phase level is below the edges of the smaller vial. By this, the MOF sample was allowed to absorb organic substrates from the gas phase. After $48 \mathrm{~h}$, the MOF sample was placed into a DMF: $\mathrm{d}^{6}$-DMSO mixture (1:1) and kept for $48 \mathrm{~h}$ again in order to desorb the substrates from the pores. The organic solvents and the ratio between the extracted organic substrates were established by comparison of relevant ${ }^{1} \mathrm{H}$ NMR intensities (see SI).

\section{X-ray Diffractometry}

Data sets for single crystals of $\mathbf{1}$ and $\mathbf{2}$ were obtained at $150 \mathrm{~K}$ on a Bruker D8 Venture diffractometer (Bruker, Billerica, MA, USA) with a CMOS PHOTON III detector and I $\mu$ S 3.0 source (mirror optics, $\lambda(\mathrm{MoK} \alpha)=0.71073 \AA$ ). Absorption corrections were applied with the use of the SADABS program. The crystal structures were solved using the SHELXT [64] and were refined using SHELXL [65] programs with OLEX2 GUI [66]. Atomic displacement parameters for non-hydrogen atoms were refined anisotropically. The available volume for solvate molecules is estimated using OLEX2 Solvent Mask Procedure to be minimum $214 \AA 3$ and $240 \AA 3$ per [ $\mathrm{M}_{2}(\mathrm{I}-\mathrm{bdc})_{2}$ (bpe)] formula unit for $\mathbf{1}$ and 2, respectively; actual space is larger due to the disorder of iodine atoms. Details of XRD experiments are given in SI (Table S1). CCDC 2142027-2142028 contains the supplementary crystallographic data for this paper.

\section{Powder X-ray Diffractometry (PXRD)}

Powder XRD data for the compounds were collected at $150 \mathrm{~K}$ by a Bruker D8 Venture diffractometer (Bruker, Billerica, MA, USA) with a CMOS PHOTON III detector and ImS 3.0 microfocus source ( $\mathrm{CuK}_{\alpha}$ radiation, collimating Montel mirrors). Powder samples were mounted on a nylon loop with a small amount of epoxy resin [67,68]. By $\varphi$-scanning $\left(360^{\circ}\right)$, Debye diffraction patterns with continuous diffraction arcs were measured. To diminish the effect of the preferred orientations, five scans were made at different positions of a goniometer for $\omega$ from $-240^{\circ}$ to $0^{\circ}$. The external standard (Si) correction and integration were performed using the Dioptas program [69]. At 298 K, PXRD analysis was performed on Shimadzu XRD-7000 diffractometer (Shimadzu Scientific Instruments Incorporated, Kyoto, Japan) (CuK-alpha radiation, Ni-filter, linear One Sight detector, 5-50 $2 \theta$ range, $0.0143^{\circ} 2 \theta$ step, 2 s per step).

\section{NMR Spectroscopy}

All NMR experiments were performed on a Bruker Avance III $500 \mathrm{MHz}$ spectrometer (Bruker, Billerica, MA, USA) at room temperature $\left(25^{\circ} \mathrm{C}\right)$.

\section{Conclusions}

We prepared two new metal-organic frameworks based on M(II), 2-iodoterephtalic acid, and bpe linkers. Both complexes reveal interpenetrating 3D structures. The Zn-based complex 1 features a relatively high gas-phase sorption selectivity for benzene:cyclohexane mixture. Despite the overall structural similarity, their adsorption selectivity towards various organic substrates is different, demonstrating that even minor changes in structure can strongly affect these characteristics. Experiments aiming preparation of other M(II)based MOFs with the same ligand combination, as well as with other iodine-substituted carboxylates, are underway in our group. 
Supplementary Materials: The following are available online: XRD, PXRD, and NMR data.

Author Contributions: Conceptualization, S.A.A., V.P.F. and M.N.S.; methodology, S.A.A. and V.P.F.; validation, S.A.A., T.S.S. and I.F.S.; formal analysis, S.A.A. and T.S.S.; investigation, T.S.S., A.S.Z. and I.F.S.; resources, S.A.A.; data curation, A.S.Z. and S.A.A.; writing-original draft preparation, S.A.A.; visualization, A.S.Z., I.F.S. and T.S.S.; supervision, S.A.A. and M.N.S.; project administration, S.A.A.; funding acquisition, S.A.A. All authors have read and agreed to the published version of the manuscript.

Funding: This work was supported by the Russian Science Foundation (Grant No. 21-73-20019) as well as the Ministry of Science and Higher Education of the Russian Federation (spectral characterization of the samples, 121031700313-8).

Institutional Review Board Statement: Not applicable.

Informed Consent Statement: Not applicable.

Data Availability Statement: Not applicable.

Conflicts of Interest: The authors declare no conflict of interest.

Sample Availability: Samples of the compounds are not available from the authors.

\section{References}

1. Furukawa, H.; Cordova, K.E.; O'Keeffe, M.; Yaghi, O.M. The chemistry and applications of metal-organic frameworks. Science 2013, 341, 1230444. [CrossRef] [PubMed]

2. Kitagawa, S.; Kitaura, R.; Noro, S.-I. Functional porous coordination polymers. Angew. Chem. Int. Ed. 2004, 43, 2334-2375. [CrossRef] [PubMed]

3. Sapchenko, S.A.; Demakov, P.A.; Samsonenko, D.G.; Dybtsev, D.N.; Schröder, M.; Fedin, V.P. A Cryptand Metal-Organic Framework as a Platform for the Selective Uptake and Detection of Group I Metal Cations. Chem.-A Eur. J. 2017, 23, $2286-2289$. [CrossRef] [PubMed]

4. Bolotov, V.A.; Kovalenko, K.A.; Samsonenko, D.G.; Han, X.; Zhang, X.; Smith, G.L.; MCormick, L.J.; Teat, S.J.; Yang, S.; Lennox, M.J.; et al. Enhancement of $\mathrm{CO}_{2}$ Uptake and Selectivity in a Metal-Organic Framework by the Incorporation of Thiophene Functionality. Inorg. Chem. 2018, 57, 5074-5082. [CrossRef] [PubMed]

5. Zhang, X.; Da Silva, I.; Fazzi, R.; Sheveleva, A.M.; Han, X.; Spencer, B.F.; Sapchenko, S.A.; Tuna, F.; McInnes, E.J.L.; Li, M.; et al. Iodine Adsorption in a Redox-Active Metal-Organic Framework: Electrical Conductivity Induced by Host-Guest Charge-Transfer. Inorg. Chem. 2019, 58, 14145-14150. [CrossRef] [PubMed]

6. Sapchenko, S.A.; Dybtsev, D.N.; Samsonenko, D.G.; Belosludov, R.V.; Belosludov, V.R.; Kawazoe, Y.; Schröder, M.; Fedin, V.P. Selective gas adsorption in microporous metal-organic frameworks incorporating urotropine basic sites: An experimental and theoretical study. Chem. Commun. 2015, 51, 13918-13921. [CrossRef]

7. Cook, T.R.; Zheng, Y.-R.; Stang, P.J. Metal-organic frameworks and self-assembled supramolecular coordination complexes: Comparing and contrasting the design, synthesis, and functionality of metal-organic materials. Chem. Rev. 2013, 113, 734-777. [CrossRef]

8. $\quad$ Lustig, W.P.; Mukherjee, S.; Rudd, N.D.; Desai, A.V.; Li, J.; Ghosh, S.K. Metal-organic frameworks: Functional luminescent and photonic materials for sensing applications. Chem. Soc. Rev. 2017, 46, 3242-3285. [CrossRef]

9. Cohen, S.M. Postsynthetic methods for the functionalization of metal-organic frameworks. Chem. Rev. 2012, 112, 970-1000. [CrossRef]

10. Kreno, L.E.; Leong, K.; Farha, O.K.; Allendorf, M.; Van Duyne, R.P.; Hupp, J.T. Metal-organic framework materials as chemical sensors. Chem. Rev. 2012, 112, 1105-1125. [CrossRef]

11. Hu, Z.; Deibert, B.J.; Li, J. Luminescent metal-organic frameworks for chemical sensing and explosive detection. Chem. Soc. Rev. 2014, 43, 5815-5840. [CrossRef] [PubMed]

12. Cui, Y.; Chen, B.; Qian, G. Lanthanide metal-organic frameworks for luminescent sensing and light-emitting applications. Coord. Chem. Rev. 2014, 273-274, 76-86. [CrossRef]

13. Zhang, Y.; Yuan, S.; Day, G.; Wang, X.; Yang, X.; Zhou, H.-C. Luminescent sensors based on metal-organic frameworks. Coord. Chem. Rev. 2018, 354, 28-45. [CrossRef]

14. Yang, Z.; Zhang, W.; Yin, Y.; Fang, W.; Xue, H. Metal-organic framework-based sensors for the detection of toxins and foodborne pathogens. Food Control 2022, 133, 108684. [CrossRef]

15. Mohan, B.; Kumar, S.; Xi, H.; Ma, S.; Tao, Z.; Xing, T.; You, H.; Zhang, Y.; Ren, P. Fabricated Metal-Organic Frameworks (MOFs) as luminescent and electrochemical biosensors for cancer biomarkers detection. Biosens. Bioelectron. 2022, 197, 113738. [CrossRef]

16. Gheorghe, A.; Lugier, O.; Ye, B.; Tanase, S. Metal-organic framework based systems for $\mathrm{CO}_{2}$ sensing. J. Mater. Chem. C 2021, 9 , 16132-16142. [CrossRef] 
17. Dey, G.; Shadab; Aijaz, A. Metal-Organic Framework Derived Nanostructured Bifunctional Electrocatalysts for Water Splitting. ChemElectroChem 2021, 8, 3782-3803. [CrossRef]

18. Li, S.; Shan, S.; Chen, S.; Li, H.; Li, Z.; Liang, Y.; Fei, J.; Xie, L.; Li, J. Photocatalytic degradation of hazardous organic pollutants in water by Fe-MOFs and their composites: A review. J. Environ. Chem. Eng. 2021, 9, 105967. [CrossRef]

19. Xia, T.; Lin, Y.; Li, W.; Ju, M. Photocatalytic degradation of organic pollutants by MOFs based materials: A review. Chin. Chem. Lett. 2021, 32, 2975-2984. [CrossRef]

20. Huang, D.; Wang, G.; Cheng, M.; Zhang, G.; Chen, S.; Liu, Y.; Li, Z.; Xue, W.; Lei, L.; Xiao, R. Optimal preparation of catalytic Metal-organic framework derivatives and their efficient application in advanced oxidation processes. Chem. Eng. J. 2021, 421, 127817. [CrossRef]

21. Zhai, Z.; Yan, W.; Dong, L.; Deng, S.; Wilkinson, D.P.; Wang, X.; Zhang, L.; Zhang, J. Catalytically active sites of MOF-derived electrocatalysts: Synthesis, characterization, theoretical calculations, and functional mechanisms. J. Mater. Chem. A 2021, 9 , 20320-20344. [CrossRef]

22. Belousov, A.S.; Suleimanov, E.V. Application of metal-organic frameworks as an alternative to metal oxide-based photocatalysts for the production of industrially important organic chemicals. Green Chem. 2021, 23, 6172-6204. [CrossRef]

23. Adegoke, K.A.; Maxakato, N.W. Porous metal-organic framework (MOF)-based and MOF-derived electrocatalytic materials for energy conversion. Mater. Today Energy 2021, 21, 100816. [CrossRef]

24. Sahoo, R.; Das, M.C. C2s/C1 hydrocarbon separation: The major step towards natural gas purification by metal-organic frameworks (MOFs). Coord. Chem. Rev. 2021, 442, 213998. [CrossRef]

25. Wu, Y.; Weckhuysen, B.M. Separation and Purification of Hydrocarbons with Porous Materials. Angew. Chem. Int. Ed. 2021, 60, 18930-18949. [CrossRef]

26. Demakov, P.A.; Sapchenko, S.A.; Samsonenko, D.G.; Dybtsev, D.N.; Fedin, V.P. Coordination polymers based on zinc(ii) and manganese(ii) with 1,4-cyclohexanedicarboxylic acid. Russ. Chem. Bull. 2018, 67, 490-496. [CrossRef]

27. Sapianik, A.A.; Kovalenko, K.A.; Samsonenko, D.G.; Barsukova, M.O.; Dybtsev, D.N.; Fedin, V.P. Exceptionally effective benzene/cyclohexane separation using a nitro-decorated metal-organic framework. Chem. Commun. 2020, 56, 8241-8244. [CrossRef]

28. Mukherjee, S.; Sensharma, D.; Qazvini, O.T.; Dutta, S.; Macreadie, L.K.; Ghosh, S.K.; Babarao, R. Advances in adsorptive separation of benzene and cyclohexane by metal-organic framework adsorbents. Coord. Chem. Rev. 2021, 437, 213852. [CrossRef]

29. Hu, J.-M.; Blatov, V.A.; Yu, B.; Van Hecke, K.; Cui, G.-H. An unprecedented "strongly" self-catenated MOF containing inclined catenated honeycomb-like units. Dalt. Trans. 2016, 45, 2426-2429. [CrossRef]

30. Ye, C.-R.; Wang, W.-J.; Chen, W.; Xiao, Y.; Zhang, H.-F.; Dai, B.-L.; Chen, S.-H.; Wu, X.-D.; Li, M.; Huang, X.-C. Harnessing Shape Complementarity for Upgraded Cyclohexane Purification through Adaptive Bottlenecked Pores in an Imidazole-Containing MOF. Angew. Chem. Int. Ed. 2021, 60, 23590-23595. [CrossRef]

31. Lysova, A.A.; Kovalenko, K.A.; Dybtsev, D.N.; Klyamkin, S.N.; Berdonosova, E.A.; Fedin, V.P. Hydrocarbon adsorption in a series of mesoporous metal-organic frameworks. Microporous Mesoporous Mater. 2021, 328, 111477. [CrossRef]

32. Bozbiyik, B.; Duerinck, T.; Lannoeye, J.; De Vos, D.E.; Baron, G.V.; Denayer, J.F.M. Adsorption and separation of n-hexane and cyclohexane on the UiO-66 metal-organic framework. Microporous Mesoporous Mater. 2014, 183, 143-149. [CrossRef]

33. Zheng, Y.; Yong, J.; Zhu, Z.; Chen, J.; Song, Z.; Gao, J. Spin crossover in metal-organic framework for improved separation of $\mathrm{C} 2 \mathrm{H} 2 / \mathrm{CH} 4$ at room temperature. J. Solid State Chem. 2021, 304, 122554. [CrossRef]

34. Wang, Y.; He, M.; Gao, X.; Li, S.; Xiong, S.; Krishna, R.; He, Y. Exploring the Effect of Ligand-Originated MOF Isomerism and Methoxy Group Functionalization on Selective Acetylene/Methane and Carbon Dioxide/Methane Adsorption Properties in Two NbO-Type MOFs. ACS Appl. Mater. Interfaces 2018, 10, 20559-20568. [CrossRef] [PubMed]

35. Meng, L.; Liu, K.; Fu, S.; Wang, L.; Liang, C.; Li, G.; Li, C.; Shi, Z. Microporous Cu metal-organic framework constructed from V-shaped tetracarboxylic ligand for selective separation of $\mathrm{C} 2 \mathrm{H} 2 / \mathrm{CH} 4$ and $\mathrm{C} 2 \mathrm{H} 2 / \mathrm{N} 2$ at room temperature. J. Solid State Chem. 2018, 265, 285-290. [CrossRef]

36. Mao, H.; Li, S.-H.; Zhang, A.-S.; Xu, L.-H.; Lu, H.-X.; Lv, J.; Zhao, Z.-P. Furfural separation from aqueous solution by pervaporation membrane mixed with metal organic framework MIL-53(Al) synthesized via high efficiency solvent-controlled microwave. Sep. Purif. Technol. 2021, 272. [CrossRef]

37. Zhou, P.; Cheng, J.; Yan, Y.; Xu, S.; Zhou, C. Ultrafast preparation of hydrophobic ZIF-67/copper mesh via electrodeposition and hydrophobization for oil/water separation and dyes adsorption. Sep. Purif. Technol. 2021, 272, 118871. [CrossRef]

38. Wei, X.; Wang, C.-C.; Li, Y.; Wang, P.; Wei, Q. The Z-scheme NH2-UiO-66/PTCDA composite for enhanced photocatalytic Cr(VI) reduction under low-power LED visible light. Chemosphere 2021, 280, 130734. [CrossRef]

39. Cavallo, G.; Metrangolo, P.; Milani, R.; Pilati, T.; Priimagi, A.; Resnati, G.; Terraneo, G. The Halogen Bond. Chem. Rev. 2016, 116, 2478-2601. [CrossRef]

40. Norouzi, F.; Khavasi, H.R. Iodine decorated-UiO-67 MOF as a fluorescent sensor for the detection of halogenated aromatic hydrocarbons. New J. Chem. 2020, 44, 8937-8943. [CrossRef]

41. Kalaj, M.; Momeni, M.R.; Bentz, K.C.; Barcus, K.S.; Palomba, J.M.; Paesani, F.; Cohen, S.M. Halogen bonding in UiO-66 frameworks promotes superior chemical warfare agent simulant degradation. Chem. Commun. 2019, 55, 3481-3484. [CrossRef] [PubMed]

42. Bertani, R.; Sgarbossa, P.; Venzo, A.; Lelj, F.; Amati, M.; Resnati, G.; Pilati, T.; Metrangolo, P.; Terraneo, G. Halogen bonding in metal-organic-supramolecular networks. Coord. Chem. Rev. 2010, 254, 677-695. [CrossRef] 
43. Novikov, A.S.; Ivanov, D.M.; Avdontceva, M.S.; Kukushkin, V.Y. Diiodomethane as a halogen bond donor toward metal-bound halides. CrystEngComm 2017, 19, 2517-2525. [CrossRef]

44. Kinzhalov, M.A.; Kashina, M.V.; Mikherdov, A.S.; Mozheeva, E.A.; Novikov, A.S.; Smirnov, A.S.; Ivanov, D.M.; Kryukova, M.A.; Ivanov, A.Y.; Smirnov, S.N.; et al. Dramatically Enhanced Solubility of Halide-Containing Organometallic Species in Diiodomethane: The Role of Solvent Complex Halogen Bonding. Angew. Chem. Int. Ed. 2018, 57, 12785-12789. [CrossRef]

45. Afanasenko, A.M.; Avdontceva, M.S.; Novikov, A.S.; Chulkova, T.G. Halogen and hydrogen bonding in cis-dichlorobis(propionitrile) platinum(II) chloroform monosolvate. Z. Krist.-Cryst. Mater. 2016, 231, 435-440. [CrossRef]

46. Zelenkov, L.E.; Ivanov, D.M.; Avdontceva, M.S.; Novikov, A.S.; Bokach, N.A. Tetrachloromethane as halogen bond donor toward metal-bound halides. Z. Krist.-Cryst. Mater. 2019, 234, 9-17. [CrossRef]

47. Torubaev, Y.V.; Skabitsky, I.V.; Saratov, G.A.; Barzilovich, P.Y. Halogen vs. ionic bonding: An unusual isomorphism between the neutral $\left(\mathrm{C}_{5} \mathrm{Me}_{5}\right)_{2} \mathrm{Fe} / \mathrm{C}_{2} \mathrm{I}_{2}$ cocrystal and ionic $\left[\left(\mathrm{C}_{5} \mathrm{Me}_{5}\right)_{2} \mathrm{Fe}\right] \mathrm{Br}_{3}$ crystal. Mendeleev Commun. 2021, 31, 58-61. [CrossRef]

48. Torubaev, Y.V.; Skabitsky, I.V. Halogen bonding in crystals of free 1,2-diiodo-ethene $\mathrm{C}_{2} \mathrm{H}_{2} \mathrm{I}_{2}$ and its $\pi$-complex [CpMn(CO) $\left.{ }_{2}\right](\pi$ $\mathrm{C}_{2} \mathrm{H}_{2} \mathrm{I}_{2}$ ). Z. Krist.-Cryst. Mater. 2020, 235, 599-607. [CrossRef]

49. Johnson, M.T.; Džolić, Z.; Cetina, M.; Wendt, O.F.; Öhrström, L.; Rissanen, K. Neutral organometallic halogen bond acceptors: Halogen bonding in complexes of PCPPdX $(X=\mathrm{Cl}, \mathrm{Br}$, I) with iodine (I2), 1,4- diiodotetrafluorobenzene (F4DIBz), and 1,4diiodooctafluorobutane (F8DIBu). Cryst. Growth Des. 2012, 12, 362-368. [CrossRef]

50. Gao, Y.J.; Li, C.; Liu, R.; Jin, W.J. Phosphorescence of several cocrystals assembled by diiodotetrafluorobenzene and three ring angular diazaphenanthrenes via CI .. N halogen bond. Spectrochim. Acta Part A Mol. Biomol. Spectrosc. 2017, 173, 792-799. [CrossRef]

51. Eliseeva, A.A.; Ivanov, D.M.; Novikov, A.S.; Kukushkin, V.Y. Recognition of the $\pi$-hole donor ability of iodopentafluorobenzene-a conventional $\sigma$-hole donor for crystal engineering involving halogen bonding. CrystEngComm 2019, 21, 616-628. [CrossRef]

52. Eliseeva, A.A.; Ivanov, D.M.; Novikov, A.S.; Rozhkov, A.V.; Kornyakov, I.V.; Dubovtsev, A.Y.; Kukushkin, V.Y. Hexaiododiplatinate(ii) as a useful supramolecular synthon for halogen bond involving crystal engineering. Dalt. Trans. 2020, 49, 356-367. [CrossRef] [PubMed]

53. Okrut, A.; Feldmann, C. $\left\{\left[\mathrm{P}(\mathrm{o}-\text { tolyl })_{3}\right] \mathrm{Br}\right\}_{2}\left[\mathrm{Cu}_{2} \mathrm{Br}_{6}\right]\left(\mathrm{Br}_{2}\right)$ An Ionic Compound Containing Molecular Bromine. Inorg. Chem. 2008, 47, 3084-3087. [CrossRef] [PubMed]

54. Hausmann, D.; Feldmann, C. Bromine-rich Zinc Bromides: $\mathrm{Zn}_{6} \mathrm{Br}_{12}(18 \text {-crown-6 })_{2} \times\left(\mathrm{Br}_{2}\right)_{5}, \mathrm{Zn}_{4} \mathrm{Br}_{8}\left(18-{ }_{-} \text {crown-6) }\right)_{2} \times\left(\mathrm{Br}_{2}\right)_{3}$, and $\mathrm{Zn}_{6} \mathrm{Br}_{12}$ (18-crown-6) $)_{2} \times\left(\mathrm{Br}_{2}\right)_{2}$. Inorg. Chem. 2016, 55, 6141-6147. [CrossRef] [PubMed]

55. Torubaev, Y.V.; Skabitskiy, I.V.; Pavlova, A.V.; Pasynskii, A.A. First structural evidence of a Se-Br-Br halogen-bonded molecular complex. New J. Chem. 2017, 41, 3606-3611. [CrossRef]

56. Puttreddy, R.; von Essen, C.; Rissanen, K. Halogen Bonds in Square Planar 2,5-Dihalopyridine-Copper(II) Bromide Complexes Eur. J. Inorg. Chem. 2018, 2018, 2393-2398. [CrossRef]

57. Puttreddy, R.; von Essen, C.; Peuronen, A.; Lahtinen, M.; Rissanen, K. Halogen bonds in 2,5-dihalopyridine-copper(ii) chloride complexes. CrystEngComm 2018, 20, 1954-1959. [CrossRef]

58. Awwadi, F.F.; Haddad, S.F.; Turnbull, M.M.; Landee, C.P.; Willett, R.D. Copper-halide bonds as magnetic tunnels; structural, magnetic and theoretical studies of trans-bis(2,5-dibromopyridine)dihalo copper(ii) and trans-bis(2-bromopyridine)dibromo copper(ii). CrystEngComm 2013, 15, 3111-3118. [CrossRef]

59. Awwadi, F.; Haddad, S.F.; Willett, R.D.; Twamley, B. The Analogy of $\mathrm{C}-\mathrm{Br} \cdots \mathrm{Br}-\mathrm{C}, \mathrm{C}-\mathrm{Br} \cdots \mathrm{Br}-\mathrm{Fe}$, and $\mathrm{Fe}-\mathrm{Br} \cdots \mathrm{Br}-\mathrm{Fe} \mathrm{Contacts}$ : Crystal Structures of (26DAPH)FeBr ${ }_{4}$ and (26DA35DBPH) ${ }_{2} \mathrm{FeBr}_{4} \cdot \mathrm{Br}$. Cryst. Growth Des. 2010, 10, 158-164. [CrossRef]

60. Awwadi, F.F.; Turnbull, M.M.; Alwahsh, M.I.; Haddad, S.F. May halogen bonding interactions compete with Cu...Cl semi-coordinate bonds? Structural, magnetic and theoretical studies of two polymorphs of trans-bis(5-bromo-2-chloro pyridine)dichlorocopper(ii) and trans -bis(2,5-dichloropyridine)dichlorocopper(ii). New J. Chem. 2018, 42, 10642-10650. [CrossRef]

61. Christine, T.; Tabey, A.; Cornilleau, T.; Fouquet, E.; Hermange, P. Syntheses of o-iodobenzyl alcohols-BODIPY structures as potential precursors of bimodal tags for positron emission tomography and optical imaging. Tetrahedron 2019, $75,130765$. [CrossRef]

62. Zaguzin, A.S.; Sukhikh, T.S.; Kolesov, B.A.; Sokolov, M.N.; Fedin, V.P.; Adonin, S.A. Iodinated vs non-iodinated: Comparison of sorption selectivity by [Zn2(bdc)2dabco]n and superstructural 2-iodoterephtalate-based metal-organic framework. Polyhedron 2022, 212, 115587. [CrossRef]

63. Liu, B.; Zhou, H.-F.; Guan, Z.-H.; Hou, L.; Cui, B.; Wang, Y.-Y. Cleavage of a C-C $\sigma$ bond between two phenyl groups under mild conditions during the construction of $\mathrm{Zn}$ (II) organic frameworks. Green Chem. 2016, 18, 5418-5422. [CrossRef]

64. Sheldrick, G.M. SHELXT-Integrated space-group and crystal-structure determination. Acta Crystallogr. Sect. A Found. Adv. 2015, 71,3-8. [CrossRef]

65. Sheldrick, G.M. IUCr Crystal structure refinement with SHELXL. Acta Crystallogr. Sect. C Struct. Chem. 2015, 71, 3-8. [CrossRef]

66. Dolomanov, O.V.; Bourhis, L.J.; Gildea, R.J.; Howard, J.A.K.; Puschmann, H. OLEX2: A complete structure solution, refinement and analysis program. J. Appl. Crystallogr. 2009, 42, 339-341. [CrossRef]

67. Alexeev, A.V.; Gromilov, S.A. Quantitative phase analysis on a single crystal X-ray diffractometer equipped with a twodimensional flat detector. J. Struct. Chem. 2010, 51, 156-165. [CrossRef] 
68. Alexeev, A.V.; Gromilov, S.A. X-Ray Diffraction Study of Micro Amounts of Polycrystalline Samples. J. Struct. Chem. 2010, 51, 744-757. [CrossRef]

69. Prescher, C.; Prakapenka, V.B. DIOPTAS: A program for reduction of two-dimensional X-ray diffraction data and data exploration. High Press. Res. 2015, 35, 223-230. [CrossRef] 